Article

\title{
Contrasting Rhizospheric and Heterotrophic Components of Soil Respiration during Growing and Non-Growing Seasons in a Temperate Deciduous Forest
}

\author{
Zhen Jiao and Xingchang Wang * \\ Center for Ecological Research, Northeast Forestry University, Harbin 150040, China; ecozhen0811@163.com \\ * Correspondence: xcwang_cer@nefu.edu.cn; Tel.: +86-451-8219-0615
}

Received: 27 November 2018; Accepted: 21 December 2018; Published: 25 December 2018

\begin{abstract}
The contributions of heterotrophic respiration $\left(R_{\mathrm{H}}\right)$ to total soil respiration $\left(R_{\mathrm{S}}\right)$ for the non-growing season, growing season, and annual period are $84.8 \%, 60.7 \%$, and $63.3 \%$, respectively.Few studies have partitioned $R_{\mathrm{S}}$ into its rhizospheric $\left(R_{\mathrm{R}}\right)$ and heterotrophic components throughout the year in northern forest ecosystems. Our objectives were to quantify the contributions of non-growing season and heterotrophic respiration. We conducted a trenching experiment to quantify $R_{\mathrm{R}}$ and $R_{\mathrm{H}}$ in a temperate deciduous forest in Northeast China over two years using chamber methods. Temperature sensitivities $\left(Q_{10}\right)$ for $R_{\mathrm{S}}$ and for $R_{\mathrm{H}}$ were both much higher in the non-growing season (November to April) than those in the growing season. The $Q_{10}$ for $R_{\mathrm{S}}$ was higher than $Q_{10}$ for $R_{\mathrm{H}}$ in both seasons, indicating a higher temperature sensitivity of roots versus microorganisms. Mean non-growing season $R_{\mathrm{S}}, R_{\mathrm{H}}$, and $R_{\mathrm{R}}$ for the two years were 94,79 and $14 \mathrm{~g}$ carbon (C) $\mathrm{m}^{-2}$, respectively, which contributed $10.8 \%, 14.5 \%$, and $4.5 \%$ to the corresponding annual fluxes (869, 547 and $321 \mathrm{~g} \mathrm{C} \mathrm{m}^{-2}$ year $^{-1}$, respectively). The contributions of $R_{\mathrm{H}}$ to $R_{\mathrm{S}}$ for the non-growing season, growing season, and annual period were $84.8 \%, 60.7 \%$, and $63.3 \%$, respectively. Using the same contribution of non-growing season $R_{\mathrm{S}}$ to annual $R_{\mathrm{S}}$, to scale growing season measurements, to the annual scale would introduce significant biases on annual $R_{\mathrm{H}}\left(-34 \mathrm{~g} \mathrm{C} \mathrm{m}^{-2} \mathrm{yr}^{-1}\right.$ or $\left.-6 \%\right)$ and $R_{\mathrm{R}}\left(16 \mathrm{~g} \mathrm{C} \mathrm{m}^{-2} \mathrm{yr}^{-1}\right.$ or $\left.5 \%\right)$.We concluded that it was important to take non-growing season measurements in terms of accurately partitioning $R_{\mathrm{S}}$ components in northern forests.
\end{abstract}

Keywords: heterotrophic respiration; autotrophic respiration; temperature sensitivity; non-growing season; temperate forest

\section{Introduction}

Soil respiration $\left(R_{S}\right)$ is estimated to be $83-108$ Pg carbon $(C) \mathrm{yr}^{-1}$ globally [1-3], which consumes

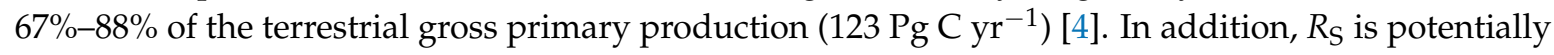
an important positive feedback for climate warming [5-7]. Thus, $R_{\mathrm{S}}$ plays an essential role in global carbon cycling.

Soil respiration is overwhelmingly comprised of heterotrophic $\left(R_{\mathrm{H}}\right.$; respiration by microbes and soil fauna) and rhizospheric $\left(R_{R}\right.$; respiration by roots, their associated mycorrhizal fungi, and other micro-organisms directly dependent on labile carbon compounds leaked from roots) components [8-10]. $R_{\mathrm{R}}$ and $R_{\mathrm{H}}$ may be driven by different mechanisms [8,11], and thus respond differently to environmental factors, both at given sites $[8,12,13]$ and globally $[14,15]$. Partitioning $R_{\mathrm{S}}$ is an important step for assessing plant physiology, $\mathrm{C}$ allocation, ecosystem $\mathrm{C}$ balance, and the climate feedback potential of changes in $R_{\mathrm{S}}$ [5,15-17]. 
Most $R_{\mathrm{S}}$ measurements in northern forests are limited in the growing season [18]. The lack of $R_{\mathrm{S}}$ studies during the non-growing season is due not only to the misconception that there is little biological activity during this period, but also to the inherent difficulties associated with cold winter sampling over snowpack [19]. However, soil respiration has been shown to continue throughout the winter in a wide variety of northern or alpine ecosystems [18,20-24]. Studies which have integrated $R_{\mathrm{H}}$ contribution to $R_{\mathrm{S}}$ throughout an entire year or growing season show a mean value of $54 \%$ for the forest ecosystem [9].The relative contributions of $R_{\mathrm{R}}$ and $R_{\mathrm{H}}$ vary during the year [25-32]. In cold climates, the $R_{\mathrm{H}}$ contribution is commonly lower than or similar to that of $R_{\mathrm{R}}$ during the growing season, and higher during the dormant periods. However, few measurements quantified $R_{\mathrm{H}}$ contribution during the winter, particularly for the snow-covered period in northern or alpine ecosystems $[25,27,33,34]$.

There are several methods for partitioning $R_{\mathrm{S}}$, each with advantages and limitations $[9,16,35,36]$. The trenching experiment is the most popular method used in boreal and temperate forest ecosystems [35], because of its simplicity and low cost [9]. Soil respiration has been partitioned by the trenching method for six forest ecosystems in the Maoershan site during growing season [28], but no direct measurements were conducted during the non-growing season [24]. In this study, the trenching approach was used throughout two successive years in a broadleaved deciduous forest. We hypothesized that using a same value of root contribution as growing season measurements throughout annual cycles would introduce significant biases in the estimating of annual $R_{\mathrm{S}}$ and its components.

\section{Materials and Methods}

\subsection{Experimental Design and Field Measurements}

This study was conducted at the Maoershan Forest Ecosystem Research Station of Northeast Forestry University, Heilongiiang Province, Northeast China $\left(45^{\circ} 24^{\prime} \mathrm{N}, 127^{\circ} 40^{\prime} \mathrm{E}, 400 \mathrm{~m}\right.$ a.s.l.). The climate is a continental monsoon climate with a windy and dry spring, a warm and humid summer, and a dry and cold winter. The mean (1989-2009) annual precipitation is $629 \mathrm{~mm}$, and mean annual air temperature is $3.1^{\circ} \mathrm{C}$. The mean January and July air temperatures are $-18.5^{\circ} \mathrm{C}$ and $22.0^{\circ} \mathrm{C}$, respectively [24]. The broadleaved deciduous forest around the eddy flux tower was $\sim 60$-years old. The dominant tree species include Ulmus japonica Sarg., Fraxinus mandshurica Rupr., Betula platyphylla Suk., Populusdavidiana Dode, Juglans mandshurica Maxim., etc. [37]. The soil is a type of alfisol with a parent rock of granite.

Eight $20 \mathrm{~m} \times 30 \mathrm{~m}$ plots were set up around the eddy flux tower in August 2007. We measured $R_{\mathrm{S}}$ during the growing season for all plots, and three plots (plot number 2-4) for the non-growing season. The basic stand characteristics were given in Table 1.

Table 1. Basic stand characteristics, soil organic carbon, and total nitrogen for the three plots.

\begin{tabular}{|c|c|c|c|c|c|c|c|c|c|}
\hline Plot Number & $\begin{array}{c}\text { BA } \\
\mathrm{m}^{2} \mathrm{~m}^{-2}\end{array}$ & $\begin{array}{l}\text { Biomass } \\
\text { Mg ha }^{-1}\end{array}$ & $\begin{array}{c}\text { Litterfall } \\
\mathrm{g} \mathrm{m}^{-2} \mathrm{yr}^{-1}\end{array}$ & $\underset{\mathrm{g} \mathrm{m}^{-2}}{\text { FRB }}$ & $\begin{array}{c}\text { FRN } \\
\mathrm{g} \mathrm{m}^{-2}\end{array}$ & $\begin{array}{c}\mathrm{SOC} \\
\mathrm{mg} \mathrm{g}^{-1}\end{array}$ & $\begin{array}{c}\mathrm{TN} \\
\mathrm{mg} \mathrm{g}^{-1}\end{array}$ & $\begin{array}{l}\text { SOC Density } \\
\mathrm{Mg} \mathrm{ha}^{-1}\end{array}$ & $\begin{array}{l}\text { TN Density } \\
\text { Mg ha }^{-1}\end{array}$ \\
\hline 2 & 19.54 & 155.09 & 459.52 & 330.33 & 253.73 & 97.51 & 9.81 & 92.22 & 9.28 \\
\hline 3 & 26.08 & 147.04 & 469.02 & 237.82 & 267.28 & 56.86 & 7.51 & 68.91 & 9.10 \\
\hline
\end{tabular}

Basal area (BA) and biomass data were from 2010. Litterfall was the mean of five $1-\mathrm{m}^{2}$ traps per plot $[38,39]$ in 2010 and 2011. Fine root (diameter $\leq 2 \mathrm{~mm}$ ) biomass (FRB) and fine root necromass (FRN) of the top $40 \mathrm{~cm}$ of soil were estimated by eight $10-\mathrm{cm}$ diameter root cores per plot in the summer of 2008. Soil organic carbon (SOC) and total nitrogen (TN) of the top $20 \mathrm{~cm}$ were measured in 2016 [40].

Four 100-cm diameter trenched subplots were established in each plot by digging a trench $(30 \mathrm{~cm}$ wide) around the outside boundary to a depth of $80 \mathrm{~cm}$ in October 2007. Trenches were lined with plastic sheets to prevent root entry and potential lateral $\mathrm{CO}_{2}$ transport [41], and refilled and packed carefully with the same soil. Eight polyvinyl chloride (PVC) collars $(10.2 \mathrm{~cm}$ inside diameter, $6 \mathrm{~cm}$ height) were randomly placed for $R_{S}$ measurements in each plot, and one collar was installed in each trenched subplot for $R_{\mathrm{H}}$ measurements. 
Since May of 2008, soil surface $\mathrm{CO}_{2}$ effluxes for control plots $\left(R_{\mathrm{S}}\right)$ and trenching subplots $\left(R_{\mathrm{H}}\right)$ were measured using an LI-COR 6400 portable infrared gas analyzer (IRGA) (LI-COR 6400, LI-COR Inc., Lincoln, NE, USA) equipped with a dynamic chamber (LI-COR 6400-9, LI-COR Inc., Lincoln, NE, USA) bi-weekly to monthly during the growing season. The measurement protocol (three cycles based on a change of $5 \mu \mathrm{mol} \mathrm{mol}{ }^{-1} \mathrm{CO}_{2}$, subsequently averaged at each collar) was similar to that used in previous soil respiration studies at this site [28,42]. Soil temperatures at $5 \mathrm{~cm}$ depth $\left(T_{5}\right)$ and $10 \mathrm{~cm}$ depth $\left(T_{10}\right)$ was simultaneously measured by a digital thermocouple, and the soil volumetric water content at the top $10 \mathrm{~cm}$ depth was detected by a Time-Domain Reflectometry (CS620, Campbell Scientific, Logan, UT, USA).

During the non-growing season, other chamber methods were adopted to measure the $R_{\mathrm{S}}$ and $R_{\mathrm{T}}$ because of LI-COR 6400 failure at low temperatures. A dark static chamber method was used from December 2009 to April 2010. Four steel collars (40 cm wide $\times 50 \mathrm{~cm}$ length) were installed in October 2009 in each plot, and the other four collars were installed in the four trenched subplots. A small vent in the chamber was used to balance the air pressure inside and outside the chamber [43]. Before each measurement, the snow around the base was removed carefully to minimize disturbance of the snow over the base. The stainless-steel statistic chamber $(40 \mathrm{~cm}$ wide $\times 50 \mathrm{~cm}$ length $\times 50 \mathrm{~cm}$ height $)$ was fitted to the collarand sealed with adhesive tape. Then the snow was quickly refilled to minimize the potential $\mathrm{CO}_{2}$ pulse from the snow hollow around the chamber base and insulate the soil from the cold air. The chamber was covered by a specific white quilt to prevent heating by solar radiation. A small fan was used to mix the gas in the chamber. Fifty $\mathrm{mL}$ gas samples were collected using fine needle syringes $0,10,20$, and $30 \mathrm{~min}$ following placement of the chamber on the base [44]. Snow depth $\left(D_{S}\right), T_{5}$, and $T_{10}$ near each chamber were also measured with a ruler and a thermocouple, respectively. Samples were transferred to evacuated gaseous bags, which were stored at room temperature. The $\mathrm{CO}_{2}$ was measured with gas chromatography (7890A GC System, Agilent Technologies, Santa Clara, CA, USA) within three days. Fluxes were calculated from the linear rate of change in gas concentration, the chamber internal volume, and soil surface area [44].

During the period of December 2010 and April 2011, the $R_{\mathrm{S}}, R_{\mathrm{H}}, T_{5}$, and $T_{10}$ were measured using a LI-COR 8100 portable IRGA equipped with a LI-COR 8100-103survey chamber (LI-COR Inc., Lincoln, NE, USA). To avoid the lateral diffusion of $\mathrm{CO}_{2}$ [33], deep soil collars (determined by snow depth, as did in reference 18) were inserted into the soil surface and stabilized for at least $10 \mathrm{~min}$ before measuring the $\mathrm{CO}_{2}$ efflux. There were four control and four trench-treatment chambers in each plot. The $D_{\mathrm{S}}$ was also measured with a ruler near each chamber of the control plot.

Continuous half-hour means of photosynthetically active radiation $(P A R)$, air temperature $\left(T_{\mathrm{a}}\right)$, soil temperature at $5 \mathrm{~cm}\left(T_{5}\right)$ and $10 \mathrm{~cm}\left(T_{10}\right)$ depths, and water content at $10 \mathrm{~cm}$ depth $\left(S W C_{10}\right)$ were measured and recorded in dataloggers (CR1000, Campbell Scientific, Logan, UT, USA), which were equipped with PAR-LITE (Kipp and Zonen, Delft, the Netherlands) at $48 \mathrm{~m}$ [39], thermometers (model 107, Campbell Scientific, Logan, UT, USA), and FDRs (EasyAG 50, Sentek, Australia) beneath the flux tower, respectively.

Different methods were used to measure soil $\mathrm{CO}_{2}$ efflux in the growing and non-growing seasons, i.e., LI-6400 in the growing season, static chamber in the first winter, and LI-8100 in the second winter. We assume that the difference between methods could be ignored. According to Pumpanen et al. [45], the chambers could be sorted into three types: closed static chamber, closed dynamic chamber, and open dynamic chamber. The static chamber could underestimate $\mathrm{CO}_{2}$ efflux, mainly due to the rising concentration within the chamber headspace [45]. Therefore, we only used this technique in the winter, when $\mathrm{CO}_{2}$ concentration increases were very small due to the small flux (generally $<0.8 \mu \mathrm{mol} \mathrm{m}^{-2} \mathrm{~s}^{-1}$ ). Previous studies verified that the LI-8100 and LI-6400 gave substantially similar results [46,47].

\subsection{Data Analysis}

Empirical models relating $R_{\mathrm{S}}$ and $R_{\mathrm{H}}$ to soil temperature and water content were developed for each plot, based on discrete measurements of $R_{\mathrm{S}}$ and $R_{\mathrm{H}}$, soil temperature, and soil water 
content (SWC), as described in Wang et al. [28,42]. Logarithmic transformation of $R_{\mathrm{S}}$ was needed to achieve linearity and homoscedasticity. A backward elimination procedure was performed to remove insignificant terms $(\alpha>0.05)$. The form of the regression models is

$$
\ln (R)=a+b \times T+c \times S W C+d \times T \times S W C
$$

where $\ln$ is natural logarithm; $R$ represents $R_{\mathrm{S}}$ or $R_{\mathrm{H}} ; T$ is the soil temperature; $S W C$ is soil water content; and $a, b, c$, and $d$ are regression coefficients.

The temperature responses of $R_{\mathrm{S}}$ and $R_{\mathrm{H}}$ were regressed by the log-transformed exponential equation

$$
\ln (R)=a+b \times T
$$

where $R$ is $R_{\mathrm{S}}$ or $R_{\mathrm{H}}$, and $a$ and $b$ are regression coefficients. Then the temperature coefficient $\left(Q_{10}\right)$ was calculated as [48]

$$
Q_{10}=\mathrm{e}^{10 b}
$$

Based on a comparison of models with different predictors (Supplementary Materials), we used the $T_{5}$ and $S W C_{10}$ to model the growing seasonal fluxes, and the $T_{5}$ for the non-growing season. The continuous $T_{5}$ and $S W C_{10}$ of the dataloggers were used to estimate the plot-specific $T_{5}$ and $S W C_{10}$ with simple linear models. Then the plot-specific $T_{5}$ and $S W C_{10}$ were used to drive the respiration models to get half-hour $R_{\mathrm{S}}$ and $R_{\mathrm{H}}[28,43]$. The seasonal and annual fluxes were the time-integrations of the half-hour $R_{\mathrm{S}}$ and $R_{\mathrm{H}}$ values [24]. The difference in $T_{5}$ and $S W C_{10}$ between the treatments was tested by a paired $t$-test at the plot scale (taking the average for each plot and each year). The effect of the difference in $S W C_{10}$ between the treatments was assessed by calculating annual flux in trenched plots $\left(R_{\mathrm{H}}\right)$ with the $S W C_{10}$ values in the control and trenched plots [49].Considering the diminishing root decomposition added by the trenching treatment [35], the measurements in the trenched plots were directly considered as $R_{\mathrm{H}}$. As a result, the $R_{\mathrm{R}}$ was calculated as the difference between $R_{\mathrm{S}}$ and $R_{\mathrm{H}}$.

In this paper, we report only the data in the last two climatic years for the three plots (numbers 2-4) to quantify the non-growing season contribution and root contribution. One reason was to avoid noncontinuous data, and the other was to minimize the effect of decomposition of newly dead roots after trenching [35].

\section{Results}

\subsection{Seasonal Variations in Soil Respiration and Related Environmental Factors}

Both air temperature $\left(T_{\mathrm{a}}\right)$ and soil temperature at $5 \mathrm{~cm}$ depths $\left(T_{5}\right)$ followed a bell-shaped curve during the study period (Figure 1a). The $T_{\mathrm{a}}$ varied from about $-30^{\circ} \mathrm{C}$ in January to a maximum of about $23^{\circ} \mathrm{C}$ in June. The $T_{5}$ generally lagged to the $T_{\mathrm{a}}$ by roughly one month, with a minimum (about $-2{ }^{\circ} \mathrm{C}$ ) in February and a maximum (about $20^{\circ} \mathrm{C}$ ) in August. Photosynthetically active radiation (PAR) peaked slightly earlier than $T_{\mathrm{a}}$ for both growing seasons, but interannually it was lower in mid-to-late summer of 2010. During the winter months, soil volumetric water content in the $10 \mathrm{~cm}$ soil layer $\left(S W C_{10}\right)$ was low $\left(0.15 \mathrm{~m}^{3} \mathrm{~m}^{-3}\right)$, and increased rapidly following snowmelt in early April (2011) or mid-April (2010; about $0.4 \mathrm{~m}^{3} \mathrm{~m}^{-3}$; Figure $\left.1 \mathrm{~b}\right)$. Snow depth $\left(D_{\mathrm{S}}\right)$ differed dramatically between the two winters. Snow depth in January was shallower for 2010, but the peak occurred in March $\left(66 \mathrm{~cm}\right.$ ) for 2010 and in January $(41 \mathrm{~cm})$ for 2011 (Figure $1 \mathrm{~b}$ ). The $R_{\mathrm{S}}$ and $R_{\mathrm{H}}$ generally followed the course of $T_{5}$ (Figure 1c). The minimum of $R_{\mathrm{S}}$ occurred in February for 2010 and in January for 2011 ( 0.11 and $0.15 \mu \mathrm{mol} \mathrm{m}{ }^{-2} \mathrm{~s}^{-1}$, respectively), and $R_{\mathrm{H}}$ occurred in January for both years ( 0.09 and $0.06 \mu \mathrm{mol} \mathrm{m}{ }^{-2} \mathrm{~s}^{-1}$, respectively). However, $R_{\mathrm{S}}$ maximized in early July while $R_{\mathrm{H}}$ peaked in late July for 2010, whereas $R_{\mathrm{S}}$ and $R_{\mathrm{H}}$ both peaked in mid-August for 2011. The difference in $R_{\mathrm{S}}$ and $R_{\mathrm{H}}$ was generally followed by $R_{\mathrm{S}}$. 

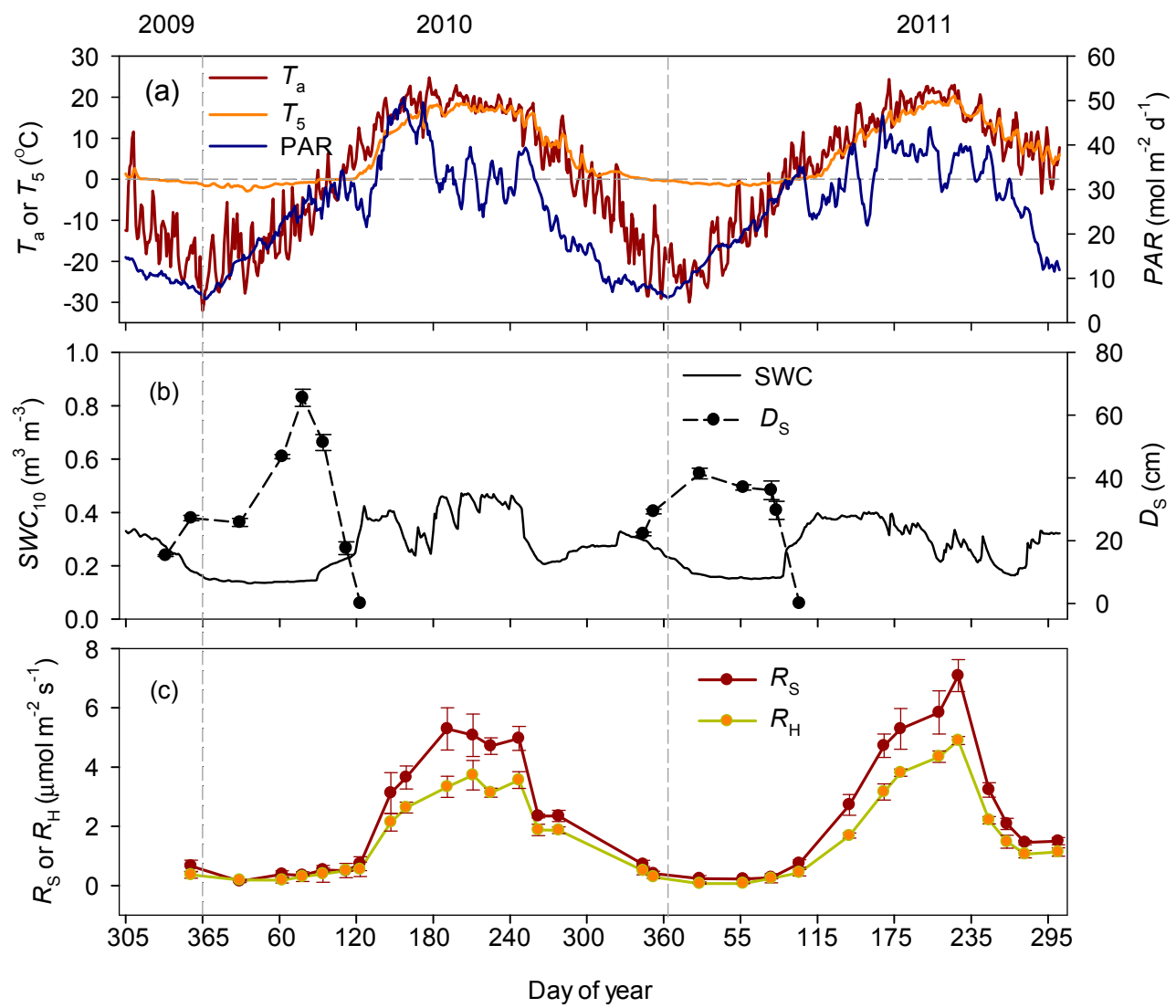

Figure 1. Seasonal dynamics of (a) daily air temperature at $16 \mathrm{~m}$ height $\left(T_{\mathrm{a}}\right)$, daily soil temperature at $5 \mathrm{~cm}$ depth $\left(T_{5}\right)$, and daily photosynthetically active radiation (PAR); (b) daily soil volumetric water content at $0-10 \mathrm{~cm}$ depth $\left(S W C_{10}\right)$, snow depth $\left(D_{\mathrm{S}}\right)$, and (c) soil $\mathrm{CO}_{2}$ efflux $\left(R_{\mathrm{S}}\right)$ and $\mathrm{CO}_{2}$ efflux from trenched plots $\left(R_{\mathrm{H}}\right)$ from November 2009 to October 2011. The error bars are standard deviations of the three plots. The vertical dash lines in the figure indicate the end of the year, and the horizontal dash line is zero temperature.

\subsection{Responses of Soil Respiration to Soil Temperature and Water Content}

Based on the log-transformed exponential model of observed $R_{\mathrm{S}}$ and $R_{\mathrm{H}}$ versus $T_{5}$, the $R_{\mathrm{S} 0}$ and $R_{\mathrm{H} 0}$ (normalized respiration rate at $0{ }^{\circ} \mathrm{C}$ for $R_{\mathrm{S}}$ and $R_{\mathrm{H}}$ ) varied between the two non-growing seasons, although $R_{\mathrm{S} 0}$ was generally higher than $R_{\mathrm{H} 0}$ (Figure 2 ). The $R_{\mathrm{S} 0}$ was higher during the non-growing season between 2009 and $2010\left(0.66 \mu \mathrm{mol} \mathrm{m}^{-2} \mathrm{~s}^{-1}\right)$ than that during the following non-growing season $\left(0.51 \mu \mathrm{mol} \mathrm{m}{ }^{-2} \mathrm{~s}^{-1}\right)$, while $R_{\mathrm{H} 0}$ was comparable between the two non-growing seasons (0.46 versus $\left.0.42 \mu \mathrm{mol} \mathrm{m}^{-2} \mathrm{~s}^{-1}\right)$.The $Q_{\mathrm{S} 10}\left(Q_{10}\right.$ for $\left.R_{\mathrm{S}}\right)$ and $Q_{\mathrm{H} 10}\left(Q_{10}\right.$ for $\left.R_{\mathrm{H}}\right)$ were lower in the non-growing season between 2009 and 2010 than in the following non-growing season. The $Q_{S 10}$ was lower than $Q_{\mathrm{H} 10}$ for both non-growing seasons (18.54 versus 11.13 for the former, and 742.48 versus 152.93 for the latter).

The $R_{\mathrm{S} 0}$ and $R_{\mathrm{H} 0}$ for the growing season $\left(0.60-1.00 \mu \mathrm{mol} \mathrm{m}^{-2} \mathrm{~s}^{-1}\right)$ were slightly higher than those for the non-growing season $\left(0.42-0.66 \mu \mathrm{mol} \mathrm{m}^{-2} \mathrm{~s}^{-1}\right)$, whereas $Q_{\mathrm{S} 10}$ and $Q_{\mathrm{H} 10}(2.34-3.06)$ were much lower than those for the non-growing season (11.13-692.29) (Figures 2 and 3). The interannual differences in $R_{\mathrm{S} 0}$ and $R_{\mathrm{H} 0}$, as well as $Q_{\mathrm{S} 10}$ and $Q_{\mathrm{H} 10}$ for the growing season, were consistent with those for the non-growing season. For both growing seasons, $R_{\mathrm{S} 0}$ was higher than $R_{\mathrm{H} 0}$ and $Q_{\mathrm{S} 10}$ was larger than $Q_{\mathrm{H} 10}$. 


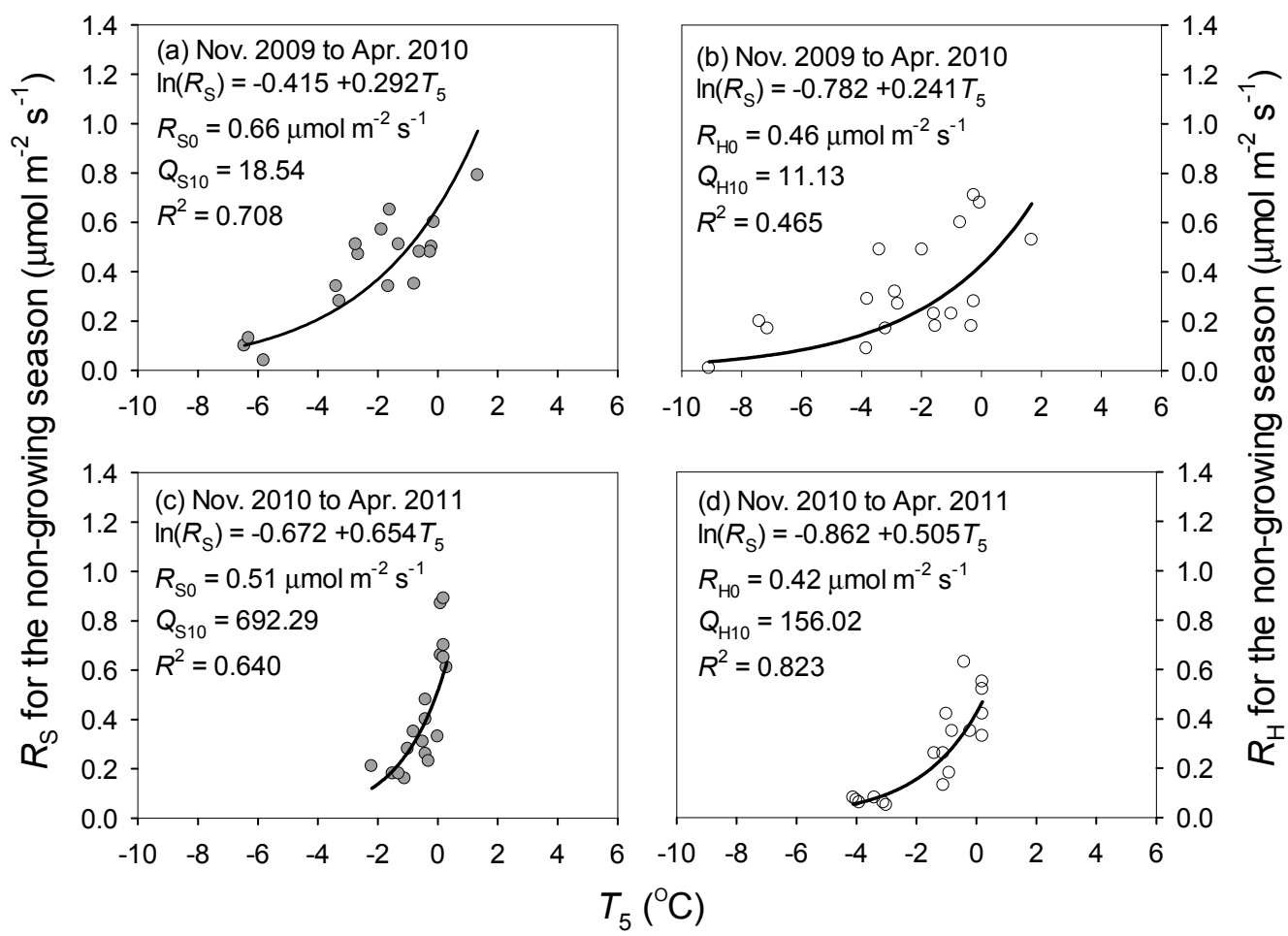

Figure 2. Relationships between soil temperature at $5 \mathrm{~cm}$ depth $\left(T_{5}\right)$ and $(\mathbf{a}, \mathbf{c})$ soil $\mathrm{CO}_{2}$ effluxes $\left(R_{\mathrm{S}}\right)$ and $(\mathbf{b}, \mathbf{d}) \mathrm{CO}_{2}$ efflux from trenched plots $\left(R_{\mathrm{H}}\right)$ during the non-growing season. The $R_{\mathrm{S} 0}$ and $R_{\mathrm{H} 0}$ are normalized respiration rate at $0{ }^{\circ} \mathrm{C}$ for $R_{\mathrm{S}}$ and $R_{\mathrm{H}}$, respectively, and $Q_{\mathrm{S} 10}, Q_{\mathrm{H} 10}$ are temperature sensitivities for $R_{\mathrm{S}}$ and $R_{\mathrm{H}}$, respectively. All $p$-values of the regression models were $<0.001$.

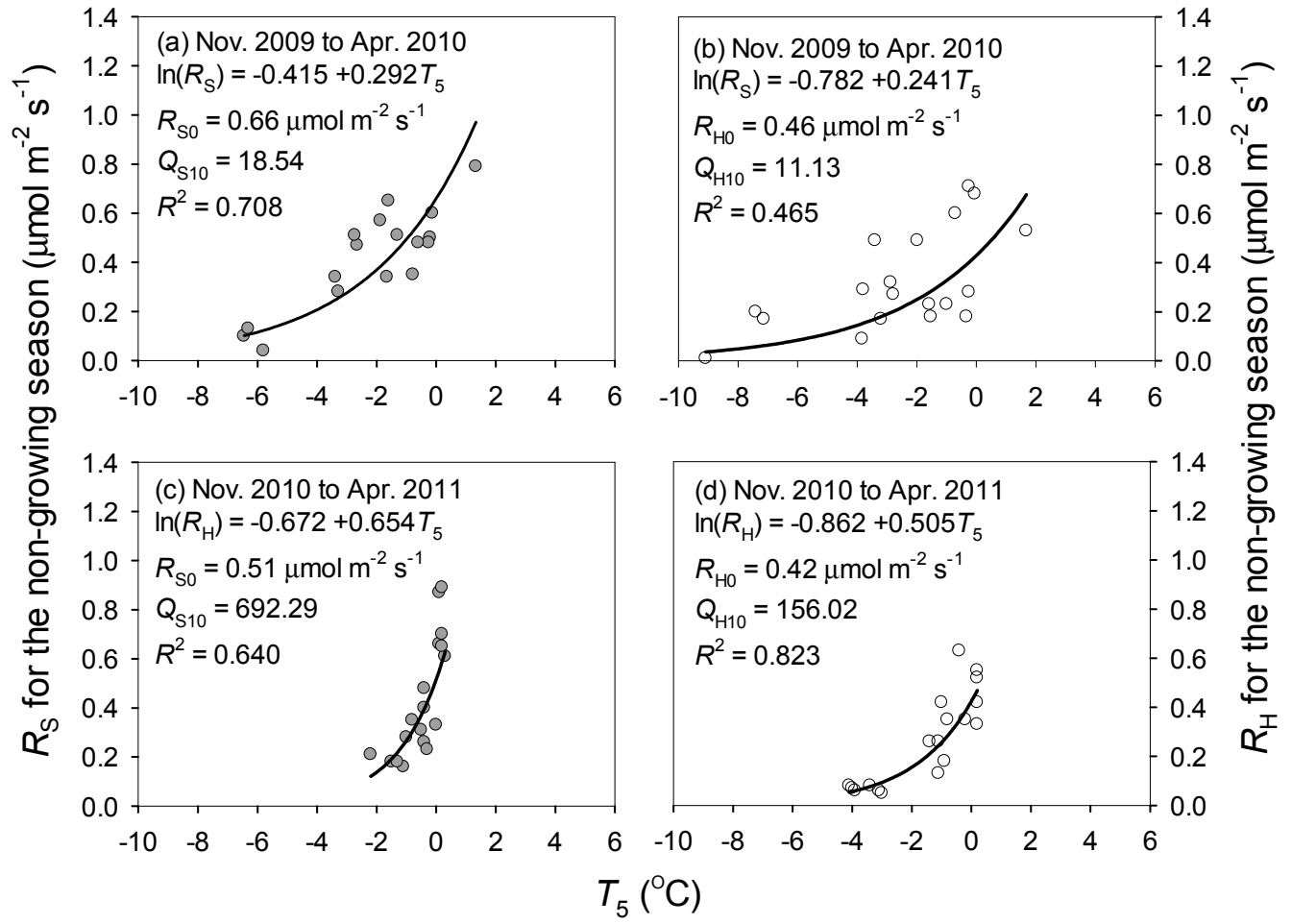

Figure 3. Relationships between soil temperature at $5 \mathrm{~cm}$ depth $\left(T_{5}\right)$ and $(\mathbf{a}, \mathbf{c})$ soil $\mathrm{CO}_{2}$ effluxes $\left(R_{\mathrm{S}}\right)$ and (b,d) $\mathrm{CO}_{2}$ efflux from trenched plots $\left(R_{\mathrm{H}}\right)$ during the growing season. The $R_{\mathrm{S} 0}$ and $R_{\mathrm{H} 0}$ are normalized respiration rate at $0{ }^{\circ} \mathrm{C}$ for $R_{\mathrm{S}}$ and $R_{\mathrm{H}}$, respectively, and $Q_{\mathrm{S} 10}, Q_{\mathrm{H} 10}$ are temperature sensitivities for $R_{\mathrm{S}}$ and $R_{\mathrm{H}}$, respectively. All $p$-vales of the regression models were $<0.001$. 
For the growing season, the statistical models of $\ln \left(R_{S}\right)$ and $\ln \left(R_{\mathrm{H}}\right)$ against $T_{5}$ and $S W C_{10}$ explained $82.5 \%-91.8 \%$ of the variability (Table 2 ). The $R_{\mathrm{S}}$ and $R_{\mathrm{H}}$ were positively correlated to soil temperature and its interactions with $S W C_{10}$ in all plots for both years, while showed varying correlations to $S W C_{10}$.

Table 2. Models of soil respiration from control plots $\left(R_{\mathrm{S}}\right.$, in $\left.\mu \mathrm{mol} \mathrm{m} \mathrm{m}^{-2} \mathrm{~s}^{-1}\right)$ and trenched plots $\left(R_{\mathrm{H}}\right.$, in $\left.\mu \mathrm{mol} \mathrm{m}{ }^{-2} \mathrm{~s}^{-1}\right)$ against soil temperature at $5 \mathrm{~cm}$ depth $\left(T_{5}\right.$, in $\left.{ }^{\circ} \mathrm{C}\right)$, and soil volumetric water content of the top $10 \mathrm{~cm}\left(S W C_{10}\right.$, in $\left.\mathrm{m}^{3} \mathrm{~m}^{-3}\right)$ for the three plots during the growing season (May to October) for 2010 and 2011.

\begin{tabular}{cccccccccc}
\hline Year & Variable & Plot & $\boldsymbol{a}$ & $\boldsymbol{b}$ & $\boldsymbol{c}$ & $\boldsymbol{d}$ & $\boldsymbol{N}$ & adj. $^{\mathbf{2}}$ & $\boldsymbol{R} \boldsymbol{M S E}$ \\
\hline 2010 & $R_{\mathrm{S}}$ & 2 & 0.44 & 0.044 & -0.837 & 0.104 & 72 & 0.842 & 0.204 \\
2010 & $R_{\mathrm{S}}$ & 3 & -0.03 & 0.091 & & & 72 & 0.874 & 0.163 \\
2010 & $R_{\mathrm{S}}$ & 4 & -0.087 & 0.092 & 0.45 & & 72 & 0.842 & 0.176 \\
2010 & $R_{\mathrm{H}}$ & 2 & 0.281 & 0.077 & -1.181 & & 36 & 0.827 & 0.222 \\
2010 & $R_{\mathrm{H}}$ & 3 & -0.178 & 0.064 & & 0.032 & 36 & 0.850 & 0.151 \\
2010 & $R_{\mathrm{H}}$ & 4 & -0.269 & 0.085 & & & 36 & 0.833 & 0.181 \\
2011 & $R_{\mathrm{S}}$ & 2 & -0.715 & 0.128 & 2.114 & & 72 & 0.878 & 0.219 \\
2011 & $R_{\mathrm{S}}$ & 3 & -0.723 & 0.112 & 2.021 & & 72 & 0.825 & 0.242 \\
2011 & $R_{\mathrm{S}}$ & 4 & -0.648 & 0.118 & 1.976 & & 72 & 0.855 & 0.218 \\
2011 & $R_{\mathrm{H}}$ & 2 & -0.502 & 0.111 & & & 36 & 0.860 & 0.237 \\
2011 & $R_{\mathrm{H}}$ & 3 & -0.873 & 0.104 & 1.654 & & 36 & 0.918 & 0.158 \\
2011 & $R_{\mathrm{H}}$ & 4 & -0.545 & 0.097 & 0.051 & & 36 & 0.849 & 0.227 \\
\hline
\end{tabular}

The regression models are of the form $\ln (R)=a+b \times T_{5}+c \times S W C_{10}+d \times T_{5} \times S W C_{10}$, where $\ln$ is natural logarithm; $R$ is $R_{\mathrm{S}}$ or $R_{\mathrm{H}}$; and $a, b, c$, and $d$ are significant coefficients $(\alpha=0.05) . N$, adj. $R^{2}$, and $R M S E$ are sample size, adjusted determination coefficient, and root mean square error, respectively. All models are highly significant $(p<0.001)$.

\subsection{Contribution of Rhizospheric and Heterotrophic Respiration}

The contributions of $R_{\mathrm{H}}$ to $R_{\mathrm{S}}$ change with integration period, with the values of $84.8 \%, 60.7 \%$, and $63.3 \%$ for the non-growing season, growing season, and annual period, respectively (Figure $4 \mathrm{a}$ ). The $R_{\mathrm{H}}$ contribution for the non-growing season was relatively $40 \%$ higher than that for growing season.
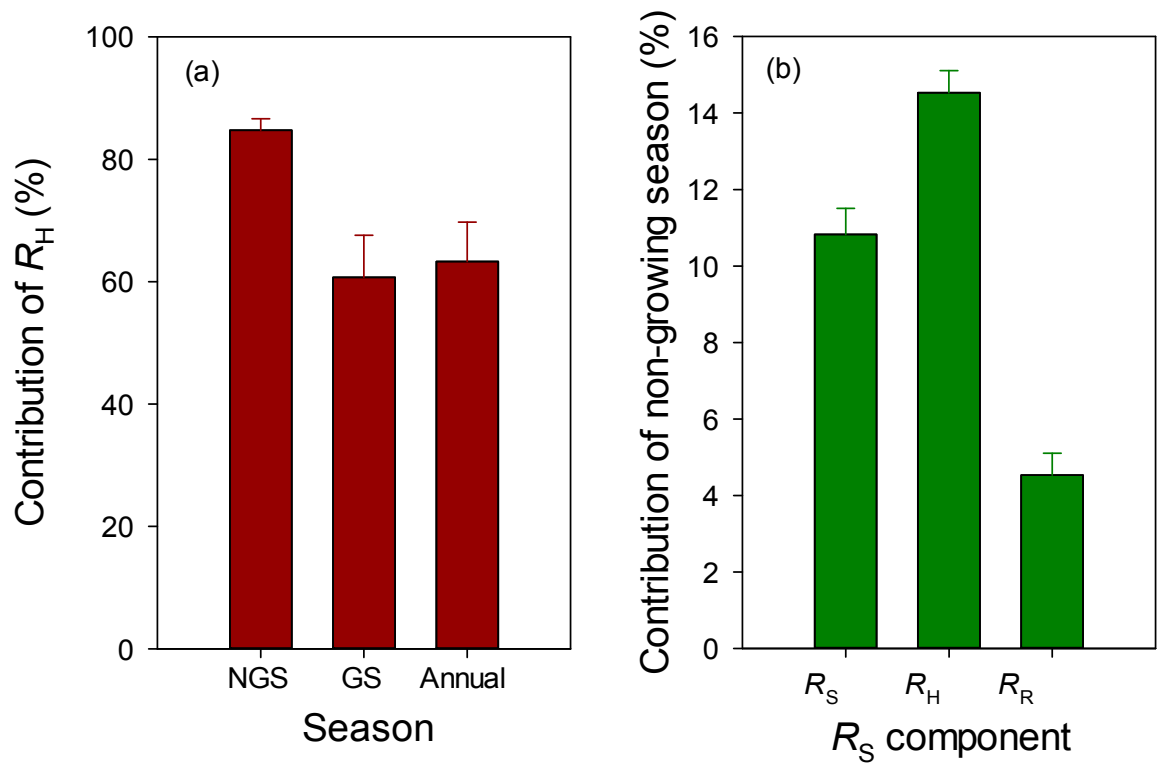

Figure 4. Contributions of the non-growing season to annual (climatic year) respiration for soil $\left(R_{\mathrm{S}}\right)$, heterotrophic $\left(R_{\mathrm{H}}\right)$, and rhizospheric $\left(R_{\mathrm{R}}\right)$ respirations $(\mathbf{a})$; the contribution of $R_{\mathrm{H}}$ to $R_{\mathrm{S}}$ for the non-growing season (NGS; from November to April), the growing season (GS; from May to October) and annual fluxes (b). The error bars are standard deviations of the three plots. 


\subsection{Contribution of Non-Growing Season Soil Respiration}

The cumulative $R_{\mathrm{S}}, R_{\mathrm{H}}$, and $R_{\mathrm{R}}$ for the non-growing season range from 84 to $103 \mathrm{~g} \mathrm{C} \mathrm{m}^{-2}$, from 75 to $84 \mathrm{~g} \mathrm{C} \mathrm{m}^{-2}$, and from 9 to $19 \mathrm{~g} \mathrm{C} \mathrm{m}^{-2}$, respectively (Table 3). The mean non-growing season $R_{\mathrm{S}}, R_{\mathrm{H}}$, and $R_{\mathrm{R}}$ were 94,79 , and $14 \mathrm{~g} \mathrm{C} \mathrm{m}^{-2}$, respectively. The mean annual $R_{\mathrm{S}}, R_{\mathrm{H}}$, and $R_{\mathrm{R}}$ were 869 , 547 , and $321 \mathrm{~g} \mathrm{C} \mathrm{m}^{-2}$ year $^{-1}$, respectively. The mean $R_{\mathrm{S}}, R_{\mathrm{H}}$, and $R_{\mathrm{R}}$ for the annual and non-growing season were given in Table S2. Therefore, the non-growing season $R_{\mathrm{S}}, R_{\mathrm{H}}$, and $R_{\mathrm{R}}$ contributed $10.8 \%$, $14.5 \%$, and $4.5 \%$ to the corresponding annual fluxes (Figure $4 \mathrm{~b}$ ). The non-growing season contribution of $R_{\mathrm{H}}$ was twice that of $R_{\mathrm{R}}$.

Table 3. Cumulative soil surface $\mathrm{CO}_{2}$ fluxes ( \pm standard deviation (SD)) in the control plot $\left(R_{\mathrm{S}}\right)$, in the trenched plot $\left(R_{\mathrm{H}}\right)$, and rhizospheric respiration $\left(R_{\mathrm{R}}\right)$. The means $\pm \mathrm{SD}$ of the three plots are given.

\begin{tabular}{ccccc}
\hline Period & Season & $\begin{array}{c}\text { Cumulative } \boldsymbol{R}_{\mathbf{S}} \\
\mathbf{g ~ C ~} \mathbf{~ m}^{-2}\end{array}$ & $\begin{array}{c}\text { Cumulative } \boldsymbol{R}_{\mathbf{H}} \\
\mathbf{g ~ C ~}^{-2}\end{array}$ & $\begin{array}{c}\text { Cumulative } \boldsymbol{R}_{\mathbf{R}} \\
\mathbf{g ~ C ~}^{-2}\end{array}$ \\
\hline November 2009-April 2010 & Non-growing season & $83.96 \pm 0.99$ & $74.80 \pm 5.19$ & $9.16 \pm 0.82$ \\
May 2010-October 2010 & Growing season & $673.35 \pm 29.26$ & $461.64 \pm 136.25$ & $211.71 \pm 27.75$ \\
Nov. 2009-October 2010 & Climatic year & $757.31 \pm 29.96$ & $536.44 \pm 141.44$ & $220.87 \pm 28.56$ \\
November 2010-April 2011 & Non-growing season & $103.47 \pm 5.33$ & $84.02 \pm 9.91$ & $19.46 \pm 3.42$ \\
May 2011-October 2011 & Growing season & $876.52 \pm 127.96$ & $473.95 \pm 211.10$ & $402.57 \pm 59.49$ \\
November 2010-October 2011 & Climatic year & $979.99 \pm 133.07$ & $557.97 \pm 220.15$ & $422.02 \pm 62.42$ \\
& Annual mean & $868.65 \pm 78.92$ & $547.20 \pm 179.63$ & $307.14 \pm 31.97$ \\
\hline
\end{tabular}

\subsection{Effects of Plot Trenching on Soil Respiration and Related Environmental Factors}

During the growing season, $T_{5}$ was $0.26{ }^{\circ} \mathrm{C}$ lower in the control plots than in the trenched plots $\left(12.99 \pm 1.22{ }^{\circ} \mathrm{C}\right.$ versus $13.25 \pm 1.36^{\circ} \mathrm{C}$; mean $\left.\pm \mathrm{SD} ; p=0.007\right)$, and the trenching effect increased $S W C_{10}$ by $0.05 \mathrm{~m}^{3} \mathrm{~m}^{-3}\left(0.30 \pm 0.03 \mathrm{~m}^{3} \mathrm{~m}^{-3}\right.$ versus $\left.0.35 \pm 0.04 \mathrm{~m}^{3} \mathrm{~m}^{-3} ; p=0.027\right)$. During the non-growing season, trenching significantly decreased $T_{5}$ by $0.68\left(-0.38 \pm 0.35^{\circ} \mathrm{C}\right.$ versus $\left.-1.06 \pm 0.60^{\circ} \mathrm{C} ; p=0.011\right)$. However, corrections for differences in $T_{5}$ and $S W C_{10}$ did not significantly reduced the $\mathrm{CO}_{2}$ efflux of the growing season ( $484 \pm 50$ versus $468 \pm 42 \mathrm{~g} \mathrm{C} \mathrm{m}^{-2} \mathrm{yr}^{-1} ; p=0.170$ ).

\section{Discussion}

\subsection{Response of Soil Respiration to Temperature}

We found the seasonal variations of $R_{\mathrm{S}}$ and $R_{\mathrm{H}}$ were generally followed by that of $T_{5}$, indicating a dominating role of temperature in respiration at the seasonal time scale. However, the different peak timing of $R_{\mathrm{S}}$ and $R_{\mathrm{H}}$ during the former growing season was a response to the lower mid-to-late summer PAR (Figure 1). This highlights the importance of a recent supply of assimilates directly to $R_{R}$, but not to $R_{\mathrm{H}}[11,50,51]$. Recently, Zhang et al. [52] verified that changes in photosynthesis drive the seasonal soil respiration-temperature hysteresis relationship, with numerical models and 129 FLUXNET sites. These findings highlight a strong necessity of component partitioning of $R_{\mathrm{S}}[8,11,28]$.

Our estimates in non-growing season $R_{\mathrm{S}}$ (generally $<0.8 \mu \mathrm{mol} \mathrm{m}^{-2} \mathrm{~s}^{-1}$ ) was well within the range of previous studies conducted in northern and subalpine forest ecosystems [24,33,53-56]. Higher rates $\left(>0.6 \mu \mathrm{mol} \mathrm{m}^{-2} \mathrm{~s}^{-1}\right)$ in a temperate mixed forest in Switzerland may be a result the high soil temperature (roughly above $3{ }^{\circ} \mathrm{C}$ ) during the dormant season [27]. A lower dormant season $R_{\mathrm{S}}$ in temperate forests (below $0.3 \mu \mathrm{mol} \mathrm{m}{ }^{-2} \mathrm{~s}^{-1}$ ) of North China [18] and in a boreal black spruce forest in Canada [25] may be due to the lower soil temperature, which reached $-10{ }^{\circ} \mathrm{C}$ at $2 \mathrm{~cm}$ depth [25] or $5 \mathrm{~cm}$ depth [18] in harsh winter. These results indicated that winter $R_{\mathrm{S}}$ was mainly controlled by soil temperature as at the Maoershan site (Figures 2 and 3).

We found that $Q_{\mathrm{S} 10}$ and $Q_{\mathrm{H} 10}$ in the non-growing season were between 11.13 and 692.29, but dropped to between 2.34 and 3.06 in the growing season. Numerous studies have demonstrated exceptionally high $Q_{10}$ for the beneath-snow respiratory flux in cold-winter ecosystems. For instance, the $Q_{\mathrm{S} 10}$ and $Q_{\mathrm{H} 10}$ in the dormant season (all above 4) were higher than those in the growing season (often <2) in two forests in the Loess Plateau of China [29]. Although our $Q_{s 10}$ of 692.29 might be 
unreasonable from a biotic view, a much higher value $\left(1.25 \times 10^{6}\right)$ was reported in a subalpine conifer forest [23]. It has been argued that the high temperature sensitivity could be attributable to the combined effects of exponential growth of snow molds, and the exponential response of their respiration rate to small changes in temperature [57].

Our $Q_{\mathrm{S10}}$ was higher than $Q_{\mathrm{H} 10}$ in both non-growing season. There was a debate on which is higher for $Q_{\mathrm{S} 10}$ and $Q_{\mathrm{H} 10}$ in the literature $[58,59]$. Lower temperature sensitivity for $R_{\mathrm{S}}$ versus $R_{\mathrm{H}}$ was reported in a mixed beech forest in Switzerland during the dormant period [27], in a boreal black spruce plantation in Canada [60], and in an oak chronosequence in China [13]. However, we found that $Q_{\mathrm{S} 10}$ was more often higher than $Q_{\mathrm{H} 10}$ in the literature $[12,14,25,29,61,62]$. The winter higher $Q_{\mathrm{S} 10}$ compared with $Q_{\mathrm{H} 10}$ indicated a higher temperature sensitivity of roots than microbes. However, the apparent $Q_{10}$ during the growing season may reflect the effect of plant phenological patterns $[48,63,64]$.

\subsection{Non-Growing Season and Annual Soil Respiration}

Our mean annual $R_{\mathrm{S}}\left(869 \mathrm{~g} \mathrm{C} \mathrm{m}^{-2} \mathrm{yr}^{-1}\right)$ was similar to that of the previous studies in broadleaved deciduous forests at the same site $\left(781-813 \mathrm{~g} \mathrm{C} \mathrm{m}^{-2} \mathrm{yr}^{-1}\right)$ [38], as well as the mean of global temperate forests $\left(829 \pm 337 \mathrm{~g} \mathrm{C} \mathrm{m}^{-2} \mathrm{yr}^{-1}\right)$ [3]. Our mean accumulated $R_{\mathrm{S}}$ for non-growing seasons (94 $\mathrm{g} \mathrm{C} \mathrm{m}^{-2}$, Table 3) was also well in the range of the reported values in temperate forests (27-132 $\mathrm{g} \mathrm{C} \mathrm{m}^{-2}$ ) [18,54,55,65-67]. Lower $R_{\mathrm{S}}$ values during the non-growing seasons between 2009 and 2010 than those between 2010and 2011 were probably due to the corresponding lower soil temperature (1.6 versus -0.5 for $T_{5}$; Figure 1a) [66]. We argue that the interannual variations in soil temperature and the corresponding $R_{\mathrm{S}}$ were mainly due to the difference in $D_{\mathrm{S}}$ before January, rather than the maximum $D_{\mathrm{S}}$ (Figure $1 \mathrm{~b}$ ). Our non-growing season contribution to annual $R_{\mathrm{S}}(10.8 \%)$ was at the low end of those in literature (6\%-23\%) $[18,24,44,54,66,68-70]$. However, the contribution of non-growing season $R_{\mathrm{H}}$ to annual $R_{\mathrm{H}}(14.5 \%)$ was over triple that of $R_{\mathrm{R}}(4.5 \%)$. Using the non-growing season $R_{\mathrm{S}}$ contribution to annual $R_{\mathrm{S}}(10.8 \%)$, to scale growing season measurements, to the annual scale would introduce substantial biases in the annual $R_{\mathrm{H}}\left(-33.70 \mathrm{~g} \mathrm{C} \mathrm{m}^{-2} \mathrm{yr}^{-1}\right.$ or $\left.-6.2 \%\right)$ and $R_{\mathrm{R}}\left(15.70 \mathrm{~g} \mathrm{C} \mathrm{m}^{-2} \mathrm{yr}^{-1}\right.$ or $4.9 \%)$.

\subsection{Contribution of Rhizospheric and Heterotrophic Respiration}

Our annual $R_{\mathrm{H}}$ contribution to $R_{\mathrm{S}}(63.3 \%)$ was slightly higher than the global means of the temperate deciduous forests: $54 \%$ by Subke et al. [35] and $~ 50 \%$ by a recent meta-analysis [14]. Our higher $R_{\mathrm{H}}$ contribution might be due to the relative higher SOC, as indicated by a positive correlation of $R_{\mathrm{H}}$ with the SOC at the same site [28]. However, our estimates of $R_{\mathrm{H}}$ contribution were much higher than those in the broadleaved deciduous forests at the same site (23\%-38\%) [28]. The discrepancy may be primarily due to different treatment of root decomposition effect.

Heterotrophic contribution varied with the seasons, which might reflect different controlling of $R_{\mathrm{R}}$ and $R_{\mathrm{H}}$. The $R_{\mathrm{H}}$ dominated $R_{\mathrm{S}}(84.8 \%)$ in the non-growing season, but its contribution declined in the growing season $(60.7 \%)$. Similar patterns were widely observed in other northern or subalpine forests $[9,12,25,27,29,71]$. For example, the contribution of $R_{\mathrm{H}}$ to $R_{\mathrm{S}}$ was lowest in the growing season ( $54 \%$ in an oak forest and $40 \%$ in a black locust plantation in the Loess Plateau, China), and it increased up to $88 \%$ and $94 \%$ during the dormant season [29]. The largest contribution of $R_{\mathrm{H}}$ to $R_{\mathrm{S}}$ was $70 \%$ during the dormant period, and as low as $41 \%$ during the summer in a mountain mixed temperate forest [27]. In a subalpine ponderosa pine plantation in the United States, the $R_{\mathrm{H}} / R_{\mathrm{S}}$ ratio varied from $44 \%$ during the growing season to $84 \%$ during the non-growing season [71]. We found that using the $R_{\mathrm{H}}$ contribution during the growing season to estimate the non-growing $R_{\mathrm{H}}$ and $R_{\mathrm{R}}$ would underestimate $R_{\mathrm{H}}$ but overestimate $R_{\mathrm{R}}$ by $22.51 \mathrm{~g} \mathrm{C} \mathrm{m}^{-2} \mathrm{yr}^{-1}$, or $7 \%$. The colder soil in the former winter had a higher $R_{\mathrm{H}}$ contribution versus the latter $(89.1 \%$ versus $81.3 \%)$, although the lower soil temperature suppressed the $R_{\mathrm{S}}$ and its components (Table 3). Reduced winter $R_{\mathrm{S}}$ was widely reported in snow removal experiments [24,54], and between years in natural conditions [66], but the partitioning of $R_{\mathrm{S}}$ is rarely reported. The reduced total respiration but increased $R_{\mathrm{H}}$ contribution indicates a higher 
temperature sensitivity of roots versus microbes. This is also supported by the higher $Q_{\mathrm{S} 10}$ versus $Q_{\mathrm{H} 10}$ (Figure 3). Therefore, a single value of $R_{\mathrm{H}}$ contribution from growing season measurements should not be applied throughout an annual cycle [9].

\subsection{Effects of Plot Trenching on Soil Respiration}

The decomposition of dead roots in trenched subplots is one of the most important uncertainties in $R_{\mathrm{S}}$ partitioning. Estimates of this effect in the literature have ranged from $2 \%$ to $54 \%$ [28,30,35,42,72], with the effect being the most pronounced within the first year after trenching, and declining to minimal levels after two years $[26,73]$ or more $[74,75]$. The estimate of error introduced by the additional decay of trenched roots for the second year following trenching indicates that $R_{\mathrm{H}}$ might be overestimated by as much as $20 \%$ in boreal forests [34] and $14 \%$ in temperate forests [64]. The root decomposition accounted for $23 \%-35 \%$ of the annual $R_{\mathrm{S}}$ in a previous study at our site [28], which might be overcorrected due to (1) overestimation of coarse root biomass using allometric equations, which did not account for the declination of root biomass with increasing distance from the stump; and (2) ignoring the carbon input of fine root mortality in natural conditions [76,77]. These uncertainties in dead root decomposition and fine root mortality cautions future studies involving the trenching method $[49,73,76,77]$.

To minimize the effect of root decomposition, we used the measurements in the third and fourth years after trenching, as done in some previous studies (e.g., [61,78]). However, measurements conducted many years after trenching might underestimate the $R_{\mathrm{H}} / R_{\mathrm{S}}$ ratio, due to a lack of below-ground litter input in trenched subplots compared with control plots [35]. Furthermore, eliminating the priming effect of root inputs in trenched plots may decrease decomposition [79], and thus underestimate $R_{\mathrm{H}}$. Therefore, we did not exclude the root decomposition in the trenched plots. Accurate estimates of $R_{\mathrm{H}}$ by trenching experiment need detailed carbon budgets in trenched plots [77].

Differences in soil moisture and temperature between control and trenched plots may be another potential artifact of the trenching experiment $[28,49]$. The increase in $T_{5}$ by trenching treatment was due to the removal of understory vegetations, which enhances the light reception of the forest floor. However, the trenching effect on $T_{5}$ reversed in the non-growing season, which might be attributed to the shallower snowpack or the disturbance introduced when measuring $\mathrm{CO}_{2}$ efflux. The increase of $S W C_{10}\left(3 \%\right.$ or $\left.0.05 \mathrm{~m}^{3} \mathrm{~m}^{-3}\right)$ by trenching might be caused by different soil drainage conditions and water uptake by trees between plots. A previous study reported that the effect of soil moisture was $16 \%$ in a pine forest in Sweden [73]. Nevertheless, $R_{\mathrm{H}}$ and its contribution to $R_{\mathrm{S}}$, based on our plot-specific $T_{5}$ and $S W C_{10}$ data and the plot-treatment-specific respiration models, may not be largely influenced by these environmental changes from trenching, because the regression models and the driving variables had already accounted for those changes.

\section{Conclusions}

Soil rhizospheric and heterotrophic respiration in a temperate deciduous forest was partitioned by a trenching experiment throughout two years. The non-growing seasons' $Q_{\mathrm{S} 10}$ and $Q_{\mathrm{H} 10}$ were both much higher than those in the growing season. Mean non-growing season $R_{\mathrm{S}}, R_{\mathrm{H}}$, and $R_{\mathrm{R}}$ for the two years was 94,79 , and $14 \mathrm{~g} \mathrm{C} \mathrm{m}^{-2}$, respectively, which contributed $10.8 \%, 14.5 \%$, and $4.5 \%$ to the corresponding annual fluxes $\left(869,547\right.$, and $321 \mathrm{~g} \mathrm{C} \mathrm{m}^{-2} \mathrm{yr}^{-1}$, respectively). The contributions of $R_{\mathrm{H}}$ to $R_{\mathrm{S}}$ for the non-growing season, growing season, and annual period were $81.3 \%, 60.7 \%$, and $63.3 \%$, respectively. Using the fixed non-growing season contribution of $R_{\mathrm{S}}$ to scale growing season measurements to the annual scale would introduce significant biases on annual $R_{\mathrm{H}}\left(-34 \mathrm{~g} \mathrm{C} \mathrm{m}^{-2} \mathrm{yr}^{-1}\right.$ or $-6 \%)$ and $R_{\mathrm{R}}\left(16 \mathrm{~g} \mathrm{C} \mathrm{m}^{-2} \mathrm{yr}^{-1}\right.$ or $\left.5 \%\right)$, and using the $R_{\mathrm{H}}$ contribution measured in the growing season to partitioning $R_{\mathrm{S}}$ in the non-growing season would overestimate $R_{\mathrm{R}}$ by $23 \mathrm{~g} \mathrm{C} \mathrm{m}^{-2} \mathrm{yr}^{-1}(7 \%$ of annual flux). We concluded that it was important to take non-growing season measurements on the partitioning of $R_{\mathrm{S}}$ components in temperate forests. 
Supplementary Materials: The following are available online at http:/ /www.mdpi.com/1999-4907/10/1/8/s1: Table S1. Models of soil respiration from control plots $\left(R_{\mathrm{S}}, \mu \mathrm{mol} \mathrm{m} \mathrm{m}^{-2} \mathrm{~s}^{-1}\right)$ and trenched plots $\left(R_{\mathrm{H}}, \mu \mathrm{mol} \mathrm{m}^{-2} \mathrm{~s}^{-1}\right)$ against soil temperature at $5 \mathrm{~cm}$ depth $\left(T_{5},{ }^{\circ} \mathrm{C}\right)$ or $10 \mathrm{~cm}\left(T_{10},{ }^{\circ} \mathrm{C}\right)$, and soil volumetric water content at $0-5 \mathrm{~cm}$ $\left(S W C_{5}, \mathrm{~m}^{3} \mathrm{~m}^{-3}\right)$ or $0-10 \mathrm{~cm}\left(S W C_{10}, \mathrm{~m}^{3} \mathrm{~m}^{-3}\right)$ for the three plots during the non-growing (November 2010 to April 2011) and growing (May to October 2011) season, Table S2. Annual and non-growing season (NGS) total soil respiration $\left(R_{\mathrm{S}}\right)$, heterotrophic respiration $\left(R_{\mathrm{H}}\right)$, and rhizospheric respiration $\left(R_{\mathrm{R}}\right)$ for each plot during the two climatic years.

Author Contributions: X.W. and Z.J. designed the experiments; Z.J. and X.W. performed field measurements; Z.J. and X.W. analyzed the data and wrote the paper.

Funding: This research was financially supported by the National Natural Science Foundation of China (30625010 and 41503071), the National Key Technology Research and Development Program of the Ministry of Science and Technology of China (No. 2011BAD37B01), and the Program for Changjiang Scholars and Innovative Research Team in University (IRT_15R09).

Acknowledgments: We are grateful to Chuankuan Wang for the help with the experimental design. We thank Yi Han for help with the field measurements. The Maoershan Forest Ecosystem Research Station provided field logistic support.

Conflicts of Interest: The authors declare no conflict of interest.

\section{References}

1. Bond-Lamberty, B.; Thomson, A. Temperature-associated increases in the global soil respiration record. Nature 2010, 464, 579-582. [CrossRef] [PubMed]

2. Hashimoto, S.; Carvalhais, N.; Ito, A.; Migliavacca, M.; Nishina, K.; Reichstein, M. Global spatiotemporal distribution of soil respiration modeled using a global database. Biogeosciences 2015, 12, 4121-4132. [CrossRef]

3. Hursh, A.; Ballantyne, A.; Cooper, L.; Maneta, M.; Kimball, J.; Watts, J. The sensitivity of soil respiration to soil temperature, moisture, and carbon supply at the global scale. Glob. Chang. Biol. 2017, 23, 2090-2103. [CrossRef]

4. Beer, C.; Reichstein, M.; Tomelleri, E.; Ciais, P.; Jung, M.; Carvalhais, N.; Rödenbeck, C.; Arain, M.A.; Baldocchi, D.; Bonan, G.B.; et al. Terrestrial gross carbon dioxide uptake: Global distribution and covariation with climate. Science 2010, 329, 834-838. [CrossRef]

5. Bond-Lamberty, B.; Thomson, A. A global database of soil respiration data. Biogeosciences 2010, 7, $1915-1926$. [CrossRef]

6. Chen, S.; Huang, Y.; Xie, W.; Zou, J.; Lu, Y.; Hu, Z. A new estimate of global soil respiration from 1970 to 2008. Chin. Sci. Bull. 2013, 58, 4153-4160. [CrossRef]

7. Zhao, Z.; Peng, C.; Yang, Q.; Meng, F.-R.; Song, X.; Chen, S.; Epule, T.E.; Li, P.; Zhu, Q. Model prediction of biome-specific global soil respiration from 1960 to 2012. Earth's Future 2017, 5, 715-729. [CrossRef]

8. Scott-Denton, L.E.; Rosenstiel, T.N.; Monson, R.K. Differential controls by climate and substrate over the heterotrophic and rhizospheric components of soil respiration. Glob. Chang. Biol. 2006, 12, 205-216. [CrossRef]

9. Hanson, P.; Edwards, N.; Garten, C.; Andrews, J. Separating root and soil microbial contributions to soil respiration: A review of methods and observations. Biogeochemistry 2000, 48, 115-146. [CrossRef]

10. Bond-Lamberty, B.; Wang, C.; Gower, S.T. A global relationship between the heterotrophic and autotrophic components of soil respiration? Glob. Chang. Biol. 2004, 10, 1756-1766. [CrossRef]

11. Högberg, P.; Nordgren, A.; Buchmann, N.; Taylor, A.F.; Ekblad, A.; Högberg, M.N.; Nyberg, G.; Ottosson-Löfvenius, M.; Read, D.J. Large-scale forest girdling shows that current photosynthesis drives soil respiration. Nature 2001, 411, 789-792. [CrossRef] [PubMed]

12. Savage, K.; Davidson, E.; Tang, J. Diel patterns of autotrophic and heterotrophic respiration among phenological stages. Glob. Chang. Biol. 2013, 19, 1151-1159. [CrossRef] [PubMed]

13. Luan, J.; Liu, S.; Wang, J.; Zhu, X.; Shi, Z. Rhizospheric and heterotrophic respiration of a warm-temperate oak chronosequence in China. Soil Biol. Biochem. 2011, 43, 503-512. [CrossRef]

14. Wang, W.; Chen, W.; Wang, S. Forest soil respiration and its heterotrophic and autotrophic components: Global patterns and responses to temperature and precipitation. Soil Biol. Biochem. 2010, 42, 1236-1244.

15. Bond-Lamberty, B.; Bailey, V.L.; Chen, M.; Gough, C.M.; Vargas, R. Globally rising soil heterotrophic respiration over recent decades. Nature 2018, 560, 80-83. [CrossRef] [PubMed] 
16. Trumbore, S. Carbon respired by terrestrial ecosystems-recent progress and challenges. Glob. Chang. Biol. 2006, 12, 141-153. [CrossRef]

17. Ryan, M.G.; Law, B.E. Interpreting, measuring, and modeling soil respiration. Biogeochemistry 2005, 73, 3-27. [CrossRef]

18. Wang, W.; Peng, S.; Wang, T.; Fang, J. Winter soil $\mathrm{CO}_{2}$ efflux and its contribution to annual soil respiration in different ecosystems of a forest-steppe ecotone, north China. Soil Biol. Biochem. 2010, 42, 451-458. [CrossRef]

19. Campbell, J.L.; Mitchell, M.J.; Groffman, P.M.; Christenson, L.M.; Hardy, J.P. Winter in northeastern North America: A critical period for ecological processes. Front. Ecol. Environ. 2005, 3, 314-322. [CrossRef]

20. Sullivan, P.F.; Welker, J.M.; Arens, S.J.T.; Sveinbjörnsson, B. Continuous estimates of $\mathrm{CO}_{2}$ efflux from arctic and boreal soils during the snow-covered season in Alaska. J. Geophys. Res. 2008, 113, G04009. [CrossRef]

21. Nobrega, S.; Grogan, P. Deeper snow enhances winter respiration from both plant-associated and bulk soil carbon pools in birch hummock tundra. Ecosystems 2007, 10, 419-431. [CrossRef]

22. Brooks, P.D.; McKnight, D.; Elder, K. Carbon limitation of soil respiration under winter snowpacks: Potential feedbacks between growing season and winter carbon fluxes. Glob. Chang. Biol. 2004, 11, 231-238. [CrossRef]

23. Monson, R.K.; Lipson, D.L.; Burns, S.P.; Turnipseed, A.A.; Delany, A.C.; Williams, M.W.; Schmidt, S.K. Winter forest soil respiration controlled by climate and microbial community composition. Nature 2006, 439, 711-714. [CrossRef]

24. Wang, C.; Han, Y.; Chen, J.; Wang, X.; Zhang, Q.; Bond-Lamberty, B. Seasonality of soil $\mathrm{CO}_{2}$ efflux in a temperate forest: Biophysical effects of snowpack and spring freeze-thaw cycles. Agric. For. Meteorol. 2013, 177, 83-92. [CrossRef]

25. Gaumont-Guay, D.; Black, T.A.; Barr, A.G.; Jassal, R.S.; Nesic, Z. Biophysical controls on rhizospheric and heterotrophic components of soil respiration in a boreal black spruce stand. Tree Physiol. 2008, 28, 161-171. [CrossRef] [PubMed]

26. Lee, M.; Nakane, K.; Nakatsubo, T.; Koizumi, H. Seasonal changes in the contribution of root respiration to total soil respiration in a cool-temperate deciduous forest. Plant Soil 2003, 255, 311-318. [CrossRef]

27. Ruehr, N.K.; Buchmann, N. Soil respiration fluxes in a temperate mixed forest: Seasonality and temperature sensitivities differ among microbial and root-rhizosphere respiration. Tree Physiol. 2010, 30, 165-176. [CrossRef]

28. Wang, C.; Yang, J. Rhizospheric and heterotrophic components of soil respiration in six Chinese temperate forests. Glob. Chang. Biol. 2007, 13, 123-131. [CrossRef]

29. Shi, W.Y.; Zhang, J.G.; Yan, M.J.; Yamanaka, N.; Du, S. Seasonal and diurnal dynamics of soil respiration fluxes in two typical forests on the semiarid Loess Plateau of China: Temperature sensitivities of autotrophs and heterotrophs and analyses of integrated driving factors. Soil Biol. Biochem. 2012, 52, 99-107. [CrossRef]

30. Brown, R.; Markewitz, D. Soil heterotrophic respiration: Measuring and modeling seasonal variation and silvicultural impacts. For. Ecol. Manag. 2018, 430, 594-608. [CrossRef]

31. Carbone, M.S.; Richardson, A.D.; Chen, M.; Davidson, E.A.; Hughes, H.; Savage, K.E.; Hollinger, D.Y. Constrained partitioning of autotrophic and heterotrophic respiration reduces model uncertainties of forest ecosystem carbon fluxes but not stocks. J. Geophys. Res. Biogeosci. 2016, 121, 2476-2492. [CrossRef]

32. Tucker, C.; Young, J.; Williams, D.; Ogle, K. Process-based isotope partitioning of winter soil respiration in a subalpine ecosystem reveals importance of rhizospheric respiration. Biogeochemistry 2014, 121, 389-408. [CrossRef]

33. Schindlbacher, A.; Zechmeister-Boltenstern, S.; Glatzel, G.; Jandl, R. Winter soil respiration from an Austrian mountain forest. Agric. For. Meteorol. 2007, 146, 205-215. [CrossRef]

34. Bond-Lamberty, B.; Wang, C.; Gower, S.T. Contribution of root respiration to soil surface $\mathrm{CO}_{2}$ flux in a boreal black spruce chronosequence. Tree Physiol. 2004, 24, 1387-1395. [CrossRef] [PubMed]

35. Subke, J.A.; Inglima, I.; Francesca Cotrufo, M. Trends and methodological impacts in soil $\mathrm{CO}_{2}$ efflux partitioning: A metaanalytical review. Glob. Chang. Biol. 2006, 12, 921-943. [CrossRef]

36. Kuzyakov, Y. Sources of $\mathrm{CO}_{2}$ efflux from soil and review of partitioning methods. Soil Biol. Biochem. 2006, 38, 425-448. [CrossRef]

37. Liu, F.; Wang, C.; Wang, X.; Zhang, J.; Zhang, Z.; Wang, J. Spatial patterns of biomass in the temperate broadleaved deciduous forest within the fetch of the Maoershan flux tower. Acta Ecol. Sin. 2016, 36, 6506-6519. 
38. Liu, Z.; Wang, C.; Chen, J.M.; Wang, X.; Jin, G. Empirical models for tracing seasonal changes in leaf area index in deciduous broadleaf forests by digital hemispherical photography. For. Ecol. Manag. 2015, 351, 67-77. [CrossRef]

39. Liu, F.; Wang, C.; Wang, X. Monitoring temporal dynamics in leaf area index of the temperate broadleaved deciduous forest in Maoershan region with tower-based radiation measurements. Chin. J. Appl. Ecol. 2016, 27, 2409-2419.

40. Kong, Q.; Wang, C.; Wang, X. Effects of detritus removal on soil carbon, nitrogen and phosphorus stoichiometry and related factors in a temperate deciduous forest in the Maoershan Mountain, China. Chin. J. Appl. Ecol. 2018, 29, 2173-2182.

41. Jassal, R.S.; Black, T.A. Estimating heterotrophic and autotrophic soil respiration using small-area trenched plot technique: Theory and practice. Agric. For. Meteorol. 2006, 140, 193-202. [CrossRef]

42. Wang, C.; Yang, J.; Zhang, Q. Soil respiration in six temperate forests in China. Glob. Chang. Biol. 2006, 12, 2103-2114. [CrossRef]

43. Davidson, E.; Savage, K.; Verchot, L.; Navarro, R. Minimizing artifacts and biases in chamber-based measurements of soil respiration. Agric. For. Meteorol. 2002, 113, 21-37. [CrossRef]

44. Groffman, P.M.; Hardy, J.P.; Driscoll, C.T.; Fahey, T.J. Snow depth, soil freezing, and fluxes of carbon dioxide, nitrous oxide and methane in a northern hardwood forest. Glob. Chang. Biol. 2006, 12, 1748-1760. [CrossRef]

45. $\mathrm{Xu}, \mathrm{M}$; $\mathrm{Qi}, \mathrm{Y}$. Soil-surface $\mathrm{CO}_{2}$ efflux and its spatial and temporal variations in a young ponderosa pine plantation in northern California. Glob. Chang. Biol. 2001, 7, 667-677. [CrossRef]

46. Pumpanen, J.; Kolari, P.; Ilvesniemi, H.; Minkkinen, K.; Vesala, T.; Niinistö, S.; Lohila, A.; Larmola, T.; Morero, M.; Pihlatie, M.; et al. Comparison of different chamber techniques for measuring soil $\mathrm{CO}_{2}$ efflux. Agric. For. Meteorol. 2004, 123, 159-176. [CrossRef]

47. Madsen, R.A.; Demetriades-Shah, T.H.; Garcia, R.L.; McDermitt, D.K. Soil $\mathrm{CO}_{2}$ Flux Measurements: Comparisons between the LI-COR LI-6400 and LI-8100; Technical Note; LI-COR Biosciences: Lincoln, NE, USA, 2004.

48. Reinmann, A.B.; Templer, P.H. Increased soil respiration in response to experimentally reduced snow cover and increased soil freezing in a temperate deciduous forest. Biogeochemistry 2018, 140, 359-371. [CrossRef]

49. Ngao, J.; Longdoz, B.; Granier, A.; Epron, D. Estimation of autotrophic and heterotrophic components of soil respiration by trenching is sensitive to corrections for root decomposition and changes in soil water content. Plant Soil 2007, 301, 99-110. [CrossRef]

50. Moyano, F.E.; Kutsch, W.L.; Rebmann, C. Soil respiration fluxes in relation to photosynthetic activity in broad-leaf and needle-leaf forest stands. Agric. For. Meteorol. 2008, 148, 135-143. [CrossRef]

51. Sampson, D.A.; Janssens, I.A.; Curiel yuste, J.; Ceulemans, R. Basal rates of soil respiration are correlated with photosynthesis in a mixed temperate forest. Glob. Chang. Biol. 2007, 13, 2008-2017. [CrossRef]

52. Zhang, Q.; Phillips, R.P.; Manzoni, S.; Scott, R.L.; Oishi, A.C.; Finzi, A.; Daly, E.; Vargas, R.; Novick, K.A. Changes in photosynthesis and soil moisture drive the seasonal soil respiration-temperature hysteresis relationship. Agric. For. Meteorol. 2018, 259, 184-195. [CrossRef]

53. Suzuki, S.; Ishizuka, S.; Kitamura, K.; Yamanoi, K.; Nakai, Y. Continuous estimation of winter carbon dioxide efflux from the snow surface in a deciduous broadleaf forest. J. Geophys. Res. 2006, 111, D17101. [CrossRef]

54. Gao, D.; Hagedorn, F.; Zhang, L.; Liu, J.; Qu, G.; Sun, J.; Peng, B.; Fan, Z.; Zheng, J.; Jiang, P.; et al. Small and transient response of winter soil respiration and microbial communities to altered snow depth in a mid-temperate forest. Appl. Soil Ecol. 2018, 130, 40-49. [CrossRef]

55. Hubbard, R.M.; Ryan, M.G.; Elder, K.; Rhoades, C.C. Seasonal patterns in soil surface $\mathrm{CO}_{2}$ flux under snow cover in 50 and 300 year old subalpine forests. Biogeochemistry 2005, 73, 93-107. [CrossRef]

56. Du, E.; Zhou, Z.; Li, P.; Jiang, L.; Hu, X.; Fang, J. Winter soil respiration during soil-freezing process in a boreal forest in Northeast China. J. Plant Ecol. 2013, 6, 349-357. [CrossRef]

57. Schmidt, S.; Wilson, K.; Monson, R.; Lipson, D. Exponential growth of "snow molds" at sub-zero temperatures: An explanation for high beneath-snow respiration rates and $Q_{10}$ values. Biogeochemistry 2009, 95, 13-21. [CrossRef]

58. Högberg, P. Is tree root respiration more sensitive than heterotrophic respiration to changes in soil temperature? New Phytol. 2010, 188, 9-10. [CrossRef]

59. Luo, Y.; Zhou, X. Deconvolution analysis to quantify autotrophic and heterotrophic respiration and their temperature sensitivities. New Phytol. 2010, 188, 10-11. [CrossRef] 
60. Bond-Lamberty, B.; Bronson, D.; Bladyka, E.; Gower, S.T. A comparison of trenched plot techniques for partitioning soil respiration. Soil Biol. Biochem. 2011, 43, 2108-2114. [CrossRef]

61. Boone, R.D.; Nadelhoffer, K.J.; Canary, J.D.; Kaye, J.P. Roots exert a strong influence on the temperature sensitivity of soil respiration. Nature 1998, 396, 570-572. [CrossRef]

62. Jiang, L.; Shi, F.; Li, B.; Luo, Y.; Chen, J.; Chen, J. Separating rhizosphere respiration from total soil respiration in two larch plantations in northeastern China. Tree Physiol. 2005, 25, 1187-1195. [CrossRef] [PubMed]

63. Curiel Yuste, J.; Janssens, I.A.; Carrara, A.; Ceulemans, R. Annual $Q_{10}$ of soil respiration reflects plant phenological patterns as well as temperature sensitivity. Glob. Chang. Biol. 2004, 10, 161-169. [CrossRef]

64. Davidson, E.A.; Janssens, I.A. Temperature sensitivity of soil carbon decomposition and feedbacks to climate change. Nature 2006, 440, 165-173. [CrossRef] [PubMed]

65. McDowell, N.G.; Marshall, J.D.; Hooker, T.D.; Musselman, R. Estimating $\mathrm{CO}_{2}$ flux from snowpacks at three sites in the Rocky Mountains. Tree Physiol. 2000, 20, 745-753. [CrossRef] [PubMed]

66. Ruehr, N.K.; Knohl, A.; Buchmann, N. Environmental variables controlling soil respiration on diurnal, seasonal and annual time-scales in a mixed mountain forest in Switzerland. Biogeochemistry 2010, 98, 153-170. [CrossRef]

67. Mo, W.; Lee, M.S.; Uchida, M.; Inatomi, M.; Saigusa, N.; Mariko, S.; Koizumi, H. Seasonal and annual variations in soil respiration in a cool-temperate deciduous broad-leaved forest in Japan. Agric. For. Meteorol. 2005, 134, 81-94. [CrossRef]

68. Kim, Y.; Ueyama, M.; Nakagawa, F.; Tsunogai, U.; Tanaka, N.; Harazono, Y. Assessment of winter fluxes of $\mathrm{CO}_{2}$ and $\mathrm{CH}_{4}$ in boreal forest soils of central Alaska estimated by the profile method and the chamber method: A diagnosis of methane emission and implications for the regional carbon budget. Tellus B 2007, 59, 223-233. [CrossRef]

69. Wang, C.; Bond-Lamberty, B.; Gower, S.T. Soil surface $\mathrm{CO}_{2}$ flux in a boreal black spruce fire chronosequence. J. Geophys. Res. 2002, 108, 8224. [CrossRef]

70. Vogel, J.G.; Valentine, D.W.; Ruess, R.W. Soil and root respiration in mature Alaskan black spruce forests that vary in soil organic matter decomposition rates. Can. J. For. Res. 2005, 35, 161-174. [CrossRef]

71. Tang, J.; Misson, L.; Gershenson, A.; Cheng, W.; Goldstein, A.H. Continuous measurements of soil respiration with and without roots in a ponderosa pine plantation in the Sierra Nevada Mountains. Agric. For. Meteorol. 2005, 132, 212-227. [CrossRef]

72. Saiz, G.; Byrne, K.A.; Butterbach-Bahl, K.; Kiese, R.; Blujdea, V.; Farrell, E.P. Stand age-related effects on soil respiration in a first rotation Sitka spruce chronosequence in central Ireland. Glob. Chang. Biol. 2006, 12, 1007-1020. [CrossRef]

73. Comstedt, D.; Boström, B.; Ekblad, A. Autotrophic and heterotrophic soil respiration in a Norway spruce forest: Estimating the root decomposition and soil moisture effects in a trenching experiment. Biogeochemistry 2011, 104, 121-132. [CrossRef]

74. Díaz-Pinés, E.; Schindlbacher, A.; Pfeffer, M.; Jandl, R.; Zechmeister-Boltenstern, S.; Rubio, A. Root trenching: A useful tool to estimate autotrophic soil respiration? A case study in an Austrian mountain forest. Eur. J. For. Res. 2010, 129, 101-109. [CrossRef]

75. Epron, D.; Farque, L.; Lucot, E.; Badot, P.M. Soil $\mathrm{CO}_{2}$ efflux in a beech forest: The contribution of root respiration. Ann. For. Sci. 1999, 56, 289-295. [CrossRef]

76. Varik, M.; Kukumägi, M.; Aosaar, J.; Becker, H.; Ostonen, I.; Lõhmus, K.; Uri, V. Carbon budgets in fertile silver birch (Betula pendula Roth) chronosequence stands. Ecol. Eng. 2015, 77, 284-296. [CrossRef]

77. Kukumägi, M.; Ostonen, I.; Uri, V.; Helmisaari, H.S.; Kanal, A.; Kull, O.; Lõhmus, K. Variation of soil respiration and its components in hemiboreal Norway spruce stands of different ages. Plant Soil 2017, 414, 265-280. [CrossRef]

78. Sulzman, E.W.; Brant, J.B.; Bowden, R.D.; Lajtha, K. Contribution of aboveground litter, belowground litter, and rhizosphere respiration to total soil $\mathrm{CO}_{2}$ efflux in an old growth coniferous forest. Biogeochemistry 2005, 73, 231-256. [CrossRef]

79. Kuzyakov, Y. Priming effects: Interactions between living and dead organic matter. Soil Biol. Biochem. 2010, 42, 1363-1371. [CrossRef]

(C) 2018 by the authors. Licensee MDPI, Basel, Switzerland. This article is an open access article distributed under the terms and conditions of the Creative Commons Attribution (CC BY) license (http://creativecommons.org/licenses/by/4.0/). 